\title{
The Role of Leader, Follower, and Situation in Leadership Interaction in National University of Jakarta
}

\author{
Rebin Sumardi ${ }^{1 \& 2} \&$ Hady Efendy ${ }^{3, *}$ \\ ${ }^{1}$ Lecturer in Economic Faculty, National University of Jakarta, Indonesia \\ ${ }^{2}$ Doctoral Program, Department of Human Resource Management, Jakarta State University, \\ Indonesia \\ ${ }^{3}$ Scientist and Academic Consultant, Indonesia \\ *Correspondence: Scientist and Academic Consultant, Indonesia. E-mail: \\ efendy_hady@yahoo.co.id
}

Received: August 15, 2017 Accepted: September 20, 2017 Published: September 29, 2017

doi:10.5296/ije.v9i3.11713 URL: https://doi.org/10.5296/ije.v9i3.11713

\begin{abstract}
Leadership in the organization is influenced how much effectiveness to achieve its goals and how the interaction between leader, followers, and situation as a single element in leadership. Interaction in leadership can produce an output and outcome of a qualified performance and become the most important part in the organization. The research on leadership interaction at National University show that leaders, followers, and situations in leadership interaction at National University have a significant role with some successes of effective leadership process in National University progress. The interaction process has resulted in a harmonious performance and its impact on the role of leader, follower and situation in advancing the National University is quite evident with the success of progress in some aspects such as strong leadership and character, honest and trust in carrying out its leadership so that the National University is able to compete to the other university.
\end{abstract}

Keywords: Follower, leader, leadership interaction, situation 


\section{Introduction}

A good organization is an organization that always adapts to the needs and development of the era. Changes are needed so that every step of the organization can work effectively and efficiently. National University (UNAS) as an organization that is quite experienced and has existed since 68 years ago. National Universities participate in private university competition must also be able to adjust themselves in the increasingly competitive conditions. To be able to win the competition in the organization of higher education, it is necessary to make changes to existing organizations.

Changes that occur are dynamic and require readiness from organization, both from systems, facilities, infrastructure and human resources. Successful change will bring an organization big and sustainable. Challenges every time cannot be detected by the leader of the organization because of many aspects to be faced and gained attention. In addition, the challenges and changes faced by the organization's leaders are interconnected and integrated.

The most common indicators used to measure the effectiveness of a leader as proposed by (Yukl, 2010: 28) are: (1) the performance level of the team or organizational unit is enhanced, and the achievement of objectives is facilitated, (2) the follower's attitude and the leader's perception, (3) The contribution of leaders to the quality of group processes, such as perceived followers or by outside observers, and (4) the degree to which a person has career success as a leader.

Only organizations that can survive and develop in the hands of effective leadership and visionary-oriented in the future. Effective leadership is able to portray leaders, followers, and situations in their interactions in leadership (Hughes, Ginnet, \& Curphy, 2009: 25). The National University with its 68 years of age is certainly experiencing the ups and downs of the journey with its current progress, but also experiencing various problems and obstacles in achieving the goals as stated in the vision, mission and objectives of the University. Therefore, it is necessary to identify the problems occurring at the National University in relation to leadership as argued by experts. Leadership variables can influence the development of the University as a vision and mission in the progress of an organization.

\section{Problem Identification and Principal Issue}

Indicators of problems in leadership at National University will be studied and analyzed the way of leadership that is:

1. Interaction in leadership leader, followwer, and situation is not harmonious;

2. Cooperation between elements of leadership is not visible in realizing the vision, mission and objectives of the university;

3. Slow development of development (progress) in the field of human resources, facilities, and infrastructure,

4. The role of university leadership that has not been optimal; 
Of the four issues mentioned above, then the discussion is focused on the relationship between the leadership, followers and situations in organizations that exist in the National University. Based on the description above, the title of this article is "The Role of Leader, Follower, and Situation in Leadership Interaction in National University (UNAS) Jakarta".

Based on the identification of the problem, then the meaning of this only focus on two aspects:

1. Interaction in leadership among leaders, followers, and situations is not harmonious;

2. Leadership cooperation does not occur in realizing the vision, mission and objectives of the university.

Referring to background and indicator of problem then the main problem of this article:

1. How is the role of leader, follower, and situation in leadership interaction towards National University progress;

2. What is the impact of the role of partner of leadership in realizing the vision, mission and goals in advancing the National University.

\section{Research Method}

Data collection techniques in this paper is to use based on the synthesis of researchers on the concepts of leadership and supported by instruments such as regulations related to the system studied, data support such as vision mission, objectives, institutional performance reports for several years, as well as direct observation at the location And associated with secondary data sources. This research methods uses a simple qualitative approach and the location of this research is the National University campus in Jl. Sawo Manila, Pasar Minggu-South of Jakarta. The time of research since the preparation of the plan until the preparation of this report during February to May 2017.

\section{Literature Review}

\subsection{Definition of Leadership}

Leadership is the process of influencing others to facilitate the attainment of objectives relevant to the organization (Ivancevich, Konopaske, \& Matteson, (2008: 413), (Wibowo, 2016: 3) Leadership uses influence in the setting of organization or situation, producing meaningful influence and Have a direct impact on the completion of challenging goals. Leaders can also be defined as a complex phenomenon involving leaders, followers, objectives, and situations (Hughes, Ginnet, \& Curphy, 2009: 4).

Whereas leadership by Greenberg \& Baron (2003: 471) gives understanding as a process in which one individual affects the members of another group toward achieving the goal of a defined group or organizational. While the Leader is the individual in the group or 
organization that most importantly affects others in the group or organization. Based on some of these definitions then taken synthesis that leadership is a way of influencing others in an effort to achieve the goal by using resources owned and controlling the situation to achieve the goal.

\subsection{Elements in Leadership}

Leadership by (Achua \& Lussier, 2010: 6) is as a process of influencing organized groups toward the completion of a comprehensive and useful objective. In an effort to achieve an organizational goal through change there are 5 elements that must be considered are:

1. Leaders-Follower. The concept as a leader or subordinate, for a person can determine his position whether as a leader or as a follower. The role of leader clearly influences the follower, but as a good follower shows the role of leadership when needed, and can also affect the leader, about his role in leadership to give and influence each other.

2. Influence. Influencing is the process of communicating ideas, obtaining information, can motivate followers to support ideas for change. Influence is the essence of leadership.

3. Organizational objective. Effective leaders will always prioritize the interests of the organization in describing the vision of the organization. Taking advantage for the interest of the follower for personal interests is not part of leadership.

4. Change. Influence and implement your organization's goal of ad sense. Organizations need to keep changing, in adjusting for the rapid changes of the global environment. An effective leader is aware of the need for continuous change to improve performance, leaders and followers must be open to change.

5. People, leadership is about leading people. In order for the goal to run effectively all activities must be with people. Effective leaders and followers enjoy working with people and helping with success.

Other opinions about the main elements and factors in leadership include only 4 main factors, as quoted Kumar M., etc., (2013), in Leadership Management, Principle, Model, and Theory Journals, as follows:

1. Leaders, leaders must have an honest understanding of who you are, what you know and what you can do. Also understand that followers will be successful if leaders are also successful. To be successful you have to convince your followers that you deserve to be a leader.

2. Follower; different people styles are different in handling followers, for example in acceptance and handling, where you start looking for a more expert and experienced. You must hurt its employees as followers.

3. Communication; two-way communication usually happens non-verbally for example when you communicate with people about what and how and how to influence in creating or disconnecting relationships between you and employees. 


\section{Macrothink Institute ${ }^{\mathrm{TM}}$}

4. Situation; each situation will be different. What you will do in the situation will be different. You should use your judgment to decide on the right action, and the style of leadership that refers to the developing situation.

\subsection{Leadership Interaction}

Understanding the leadership process takes a lot of energy to understand an effective leadership character. Effective leaders are leaders who are good at managing resources and also variables that become an integral part, but we not only up there in learning leadership, but must learn comprehensively. How his personality, his intelligence, his interpersonal skills, technical training, or motivation. Richard L. Hughes, \& Robert etc. in Leadership (2009: 26) suggests that in order to get a broader picture of the leadership process, we must use all three factors (Wibowo, 2016: 35): leaders, followers, and situations.

This approach is called interactional framework (Hughes, Ginnett, \& Curphy, 2009: 25). According to this approach are three functions of:

1. The leader: concerning personality, position, expertise, etc.;

2. The follower concerns: value, norm, cohesiveness, etc.;

3. The Situation concerning: task, stress, environment etc.

To clarify this interaction can be described as follows:

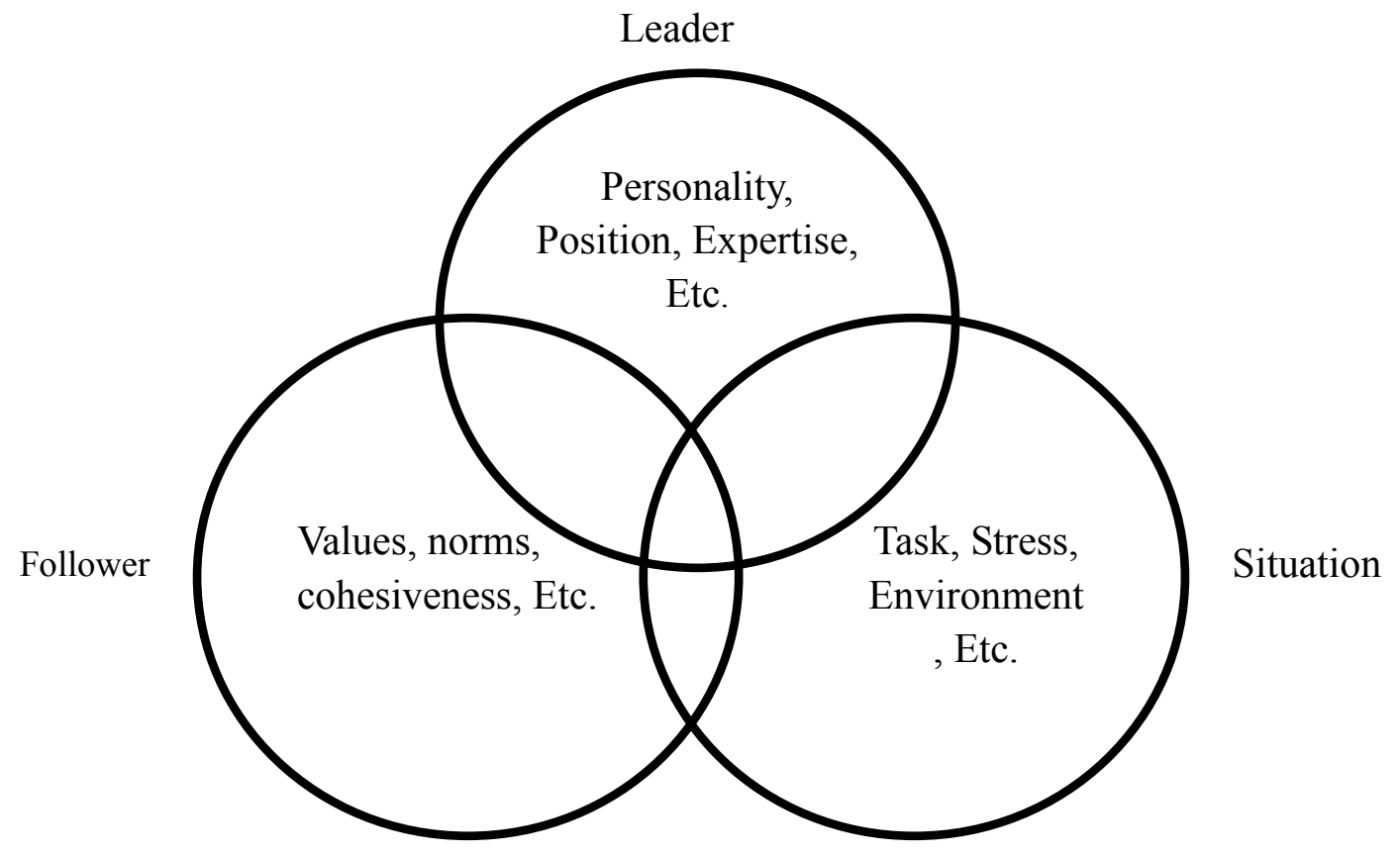

Figure 1. Interactional Leadership Framework

Source: Richard L. Hughes, Robert C. Ginnett, and Gordon J. Curphy, 2009:26.

Based on the above framework image that leadership is the result of a complex set of interactions between leaders, followers and situations. 


\subsection{Leadership Effectiveness}

In a simple way a leader can be said to be effective if it can achieve predetermined goals and targets. In the opinion of Colquitt, Le Pine, \& Wesson (2015: 448) effectiveness is determined by tactics in the way leaders renew, with some of the following tactics:

1. Most efktif, consisting of rational persuation, consultation, inspirational appeal, and collaboration.

2. Moderately effective, consisting of Ingratiation, personal appel, exchange, and Appraising.

3. Least effective, consisting of: pressure, coallicitiom.

Leadership effectiveness among others is shown by the nature of leaders in dimensions intelligentsia, personality, and abilities or intelligence, personality, and ability.

\section{Result and Discussion}

\subsection{Leader's Role in Leadership at National University of Jakarta.}

Referring to the definition of leadership put forward by Greenberg \& Baron (2003: 471) provides an understanding as a process in which one individual affects the other group members toward achieving defined organizational or organizational objectives. The Leader is the individual within the group or organization that most importantly affects others in the group or organization.

Thus the individual affecting the member of the group or member of the organization in question is the leader. The Leader at the National University is an individual leader who is in the National University leadership structure collectively consisting of the Rector and the Vice Rector according to the Statute of National University of 2009 Article 15 which is "The meaning of the Head of the University is the Rector and the Vice Rectors".

Leaders of the university in the leadership process have taken part in the decisions that have been defined as the goals of the National University organizations such as the vision, missions and goals of the National University. Principles of leadership at the National University as written by (Hughes, Ginnett, \& Curphy, 2009: 25). According to this approach is one of three functions of: The leader; consists of: personality, position, expertise, and so on. This has been done in accordance with the provisions based on the main duties and functions of each unit leader arranged in the rector's decree on the organization and management of the National University, while to be a leader regarding the specifications and personal criteria governed by the rector decree on the provisions of the terms of position in employment regulations. Leaders in various existing units have performed their roles and functions in performing the tasks and functions as specified such as the short-term and long-term objectives translation, by implementing the specified work program. Personality becomes a prescribed requirement to be a leader at the university, where in writing someone who has a good personality can be given a position as a leader for all strata or existing structures. A 
person who is judged to have good personality characteristics is given a mandate to be a leader.

The leadership position at the National University will consider one's expertise and competence in positioning a leader in an appropriate position with the "right man in the right place" principle. Only a leader who has the skills and competencies and personality that meet the requirements of the rules that can serve as the leadership at the National University. Leaders who have the ability to describe the objectives and work program on each unit of work is considered able to affect the followers or the men who are the responsibility. Each head unit has a target task and function in carrying out its work. Through empowerment then the leadership function in each hierarchy with different loads and specifications.

Leadership factors such as personality, still a focus on human resource improvement, as well as competency factors are still lacking. This condition is in accordance with the increasing demands of competence. Competence to become a leader is higher along with the development of the era especially from education sector, skill to become leader. The success of a leader in carrying out this leadership task successfully with reference to the success of building a good academic system and appropriate applicable university standards from the Ministry of Research and Technology Higher Education. Technology plays an important role as a support in establishing the Education system with the application of online lectures in response to educational demands. Technologically and information the National University is not left behind compared with the top university in Jakarta.

Improvement of the implementation of "Tridarma Perguruan Tinggi" has been perceived benefits by building a web of National University with academic applications connected to the financial administration. Likewise, the human resource development system has been using the integrated HR and financial apparatus tools with payroll and up-to-date lecturers' absenteeism due to payroll system, academic lecturer academic rank system, and library online. The student affairs sector has also refined itself with services equipped with online services.

The system built in several units of the rectorate, dean until the supporting units already using online service-based system, so it can help the service more effective and efficient. The success of the leader is the success of followers, so that the success of the leaders at the university is the success of the followers staff both lecturers and employees (educational staff). There is no leadership success then no followers' success.

Leadership existed since 1949 with the leader / first rector, Prof. Soedjadi Setyonegoro during the period 1949-1951 was an educational figure who struggled hard to establish the first private higher education in Jakarta. During his leadership the National University has gained recognition from the Indonesian Ministry of Education, Teaching and Culture, based in Yogjakarta as a private university, giving full recognition and parity to the National Academy by letter no. 548 / S. Rector II and up to now 7 with various progress and achievements in developing the university. 


\subsection{Follower's Role in Leadership at National University of Jakarta}

Referring to the definition of leadership and interaction as expressed by Hughes, Ginnett, \& Curphy, (2009: 25) interactions are also conducted with followers, in which one individual affects the other group members toward achieving defined organizational or organizational goals. The group in question at the National University are the lecturers and employees. Lecturers and employees are an important element in leadership because the organization without follower is meaningless and nothing.

Lecturers and employees are an important factor in leadership at the university, without lecturers and employees, the university cannot provide education services to its students as its main customer. Lecturers and employees hold values, norms, and cohesiveness. In the context of the role and function are on the values of honor in carrying out the educational and teaching functions to its students, including the value of the code of ethics in accordance with the provisions of the job descriptions and responsibilities respectively. The determination of the values and norms shall be stipulated in the rector's decree on the norms and the code of ethics of lecturers and employees which includes obligations and prohibitions in performing their duties.

Principles that exist in the academic are respected so that the lecturers do according to the values and codes of ethics that have been determined. The duties and responsibilities in carrying out duties for lecturers are determined through academic policies determined by university leaders. In the policy on the main task of lecturers is to carry out the activities of "Tridarma Perguruan Tinggi" consists of education, research, and community service. This leadership process is utilized through academic provision policy, for example with the Indonesian National Work Competency Standards (SKKNI) established and in its implementation through training and coordination process to each lecturer by the university's leadership and faculty leader.

Faculty leaders provide socialization about the implementation of teaching by referring to the teaching unit, and how to outline the teaching program through the existing credit system semester unit (SKS). Likewise in the leadership process to conduct research. Lecturers are given the role to undertake research facilitated by the university's leaders in research guidelines and community service. The role of the lecturers and employees in carrying out the duties and responsibilities given by the leadership based on the ability of personality and the competence of each lecturer. Role as an employee is a supporter in the implementation of education. Administrative employees have the role to provide facilities and infrastructure for the purposes of lectures and perform their duties and functions in accordance with the provisions set forth in the personnel regarding the rights and obligations. The success of employees will support the success of the leadership, so the role of followers here both lecturers and employees have a strategic function.

Sense of cohesiveness and togetherness will be felt when the communication relationship is well established between the leadership and subordinates. Cohesiveness will go up if the individual can keep togetherness and cohesiveness as a team. Together team members will produce good productivity. A low or decreased cohesiveness will degrade the performance of 
a team, if each employee cannot cooperate and bring their own ego.

\subsection{The Role of Situation in Leadership in National University of Jakarta}

Hughes, Ginnett, \& Curphy, (2009: 25) write that leadership interaction is not only between leader, and follower but also involving the situation. Situation consists of task, stress, and environment. In the National University the role of the situation is the existence of situations related to the duties of stakeholders, both leaders and followers. The tasks given to the lecturers and employees should be done appropriately taking into account the situation and conditions. The process of delivering tasks in accordance with the right time and competency will bring about the impact of performance improvement. Overloaded work volumes will lead to unsuccessful lecturers and employees. Therefore, it is necessary to have a clear measure of assigning tasks with appropriate time and work volume to be implemented. For example, a lecturer at a normal human level can only accept teaching assignments with 3 courses. However, given the burden above the reasonableness of the quality of teaching to be down. Pattern relationship between leadership and followers can also cause stress due to miscommunication factors.

Environmental factors have an important role. A supportive environment with good facilities and infrastructure will create an effective leadership process, where each proses achievement of targets and goals is influenced by both internal and external environment. The role of internal environment such as good relationships among academicians such as lecturers, employees and students. Physical environments such as comfortable working spaces will create a great atmosphere for work, lighting and coloring in the workspace and lecture halls will support the expected academic atmosphere, as is the case with other universities.

\section{Conclusion}

From the results of the above research results can be concluded:

1. The relationship between leader, follower, and situation in leadership interaction at National University has a pretty good role. This can be seen from some of the successes of the leadership process that is effective in National University progress;

2. The impact on the role of leaders, follower and situation in advancing the National University appears to be the success of progress in some aspects, although not in all aspects.

3. The leadership process has proven that the existence of the university is proven to have a long history as a university of struggle (as granted by the first Indonesian President, Ir. Sukarno to National University). 


\section{Recommendations}

1. Based on the results already obtained and the progress made by the National University so far, success should be able to exceed current results.

2. The National University can develop faster and become a leader for private universities in Indonesia, if attention and concentration on process oriented to modern leadership, with aspects that include facilities, infrastructure and human resources in implementing a modern university organization and high quality.

3. The construction of facilities and infrastructure of the National University is slow, so there is a need for leadership that has a vision to the future, by inviting stakeholders who have commitment and big capital to be willing to give capital to develop the National University to have various modern facilities and have the ability to compete as a university research.

\section{References}

Achua, Cristoper F., \& Robert N Lusser. (2010). Effective Leadership. Singapore. South-western.

Billy Tunas. (2010). Pendekatan Sistem. Nimas Multima. Jakarta.

Colquitt, J. A., Le Pine, J. A., \& Wesson, M. J. (2015). Organizational Behavior: Improving Performance and Commitment in the Workplace (4th Ed.). New York: McGraw-Hill Education.

Greenberg, Jerald \& Robert A. Baron. (2003). Behaviour in Organizations, Understanding and Managing The Human Side of Work (3th Ed.). Allin \& Bacon. A Division of Schuster. Massachusetts.

Hughes, R. L., Ginnett, R. C., \& Curphy. G. J. (2009). Leadership: Enhancing the lessons of experience (6th Ed.). New York: McGraw Hill.

Ivancevich, Konopaske, \& Matteson. (2008). Organizational Behavior and Management. New York: McGraw-Hill International.

Kumar, M, Miss Shilpa etc. (2013). Global Journal Management and Business. Journal Leadership Management: Principle, Model, and Theory. Vol 3-Number 3,

Richard L. Hughes, Robert C. Ginnett, \& Gordon J. Curphy. (2009). Leadership: Enhancing the Lessons of Experience. (6th Ed.). McGraw-Hill/Irwin (2009).

UNJ- Pascasarjana. (2012). Buku Pedoman Penulisan Tesis dan Disertasi. UNJ-Jakarta.

Wibowo. (2016). Kepemimpinan; Pemahaman Dasar, Pandangan Konvensional, Gagasan dan Kontemporer. Rajagrafindo, Jakarta.

Yukl, G. (2010). Leadership in Organizations (7th Ed.). New Jersey: Prentice Hall. 


\section{Copyright Disclaimer}

Copyright for this article is retained by the author(s), with first publication rights granted to the journal.

This is an open-access article distributed under the terms and conditions of the Creative Commons Attribution license (http://creativecommons.org/licenses/by/3.0/). 